\title{
A Comparative Study of Agricultural Support Institutions in Central Province of Zambia: A Historical and Spatial Analysis
}

\author{
Augrey H. Malambo ${ }^{1}$ \\ ${ }^{1}$ University of Zambia, Geography Department, School of Natural Sciences, P.O. Box 32379, Lusaka, Zambia \\ Correspondence: Augrey H. Malambo, University of Zambia, Geography Department, School of Natural \\ Sciences, P.O. Box 32379, Lusaka, Zambia. E-mail: augrey.malambo@yahoo.com
}

Received: July 23, 2013 Accepted: August 15, 2013 Online Published: August 28, 2013

doi:10.5539/jgg.v5n3p226 URL: http://dx.doi.org/10.5539/jgg.v5n3p226

\begin{abstract}
This is a comparative study of agricultural support institutions in Central Province, Zambia focusing on the 1980-90 and 1997-2008 periods. Generally, the study intended to identify the names of agricultural support institutions which existed in Central Province, as a smaller unit, and Zambia in general, and analyze their spatial aspect. In order to achieve this and other goals, the investigation conducted an extensive review of existing literature, old and new maps, distribution of questionnaires to informants, interviews, Focus Group Discussions and observations. The main thesis of this study was that agricultural support institutions differed in nature, funding, control and spatiality over different periods in Zambia's history.

The major findings were that both private and government agricultural support institutions existed soon after independence up to 1973 when the Zambian government declared a one party system and thereby nationalizing over $90 \%$ of the agricultural industry. Thus, the majority of agricultural support institutions between 1973 and 1990 were government funded, owned and controlled parastatal organizations such as National Agriculture Marketing Board (NAMBOARD), Zambia Cooperative Federation (ZCF) and Lima Bank. These institutions had both a regional and national character, and were spatially more widely distributed. After the introduction of multi party politics and liberalization economic policies in 1991, the institutions collapsed due to withdraw of subsidies by government and, new, largely privately owned institutions, emerged such as Miombo and Omnia Fertilizer companies, Maize Research Institute (MRI), among others. Institutions which emerged after 1991 were more limited in distribution but more financially independent and sustainable. However, after 1997, the government intervened in the agricultural industry again by establishing the Food Reserve Agency (FRA) and Farmer Input Support Programme (FISP). FRA was the conduit through which government bought crops especially maize while FISP was used to distribute subsidized maize seed and eight bags of chemical fertilizers to selected members of cooperatives. The study concludes that different agricultural support institutions have existed at different periods of Zambia's history and their spatial distribution has been changing depending on their resource base.
\end{abstract}

Keywords: agriculture, agricultural support institutions, agricultural liberalization, central province, cooperative societies, Chibombo district, economic liberalization, Kapiri Mposhi district, private sector, and public sector/government controlled, Mumbwa district, small scale farmer, Zambia

\section{Introduction}

\subsection{General Introduction and Background}

Agricultural support institutions world over evolve with time in terms of their nature, scope, funding, spatial distribution, efficiency and management. Agricultural support institutions in Zambia have not been immune to such developments. This study focused on identifying the various institutions which have been involved in supporting small scale crop agriculture in Zambia since independence, in general, and Central Province, in particular. The study brought out specific names of the institutions, years when they were established, their geographical distribution, funding, control and their functions. The main thesis of this current study is that institutions which existed in the colonial period differed from those which emerged after independence. Similarly, the study argues that institutions of the immediate post independence period between 1964 and 1973 differed from those which emerged in the period of one party rule between 1973 and 1990; and these differed from those which emerged in the period of multi party politics of liberalization after 1991. 
The evolution of agricultural support institutions is not unique to Zambia alone (Mwanza, 1992). Several scholars argue that institutional changes emanating from policy shifts have occurred in Africa among countries such as Malawi (Kaluwa et al., 1992), Tanzania (Shao et al., 1992) and Zimbabwe (Kadenge et al., 1992); in Latin America Argentina and Chile (Gerrard et al., 1994; World Bank, 1994), and several East European countries emerging from communist economic structures (World Bank, 1995). Generally, adjustments have differed in terms of scope, rate of implementation and results because of variations in culture, government policies and pressures, environmental conditions and goals. For instance, in Southern Africa, Zambia is viewed as one country which implemented institutional adjustments rapidly especially after the government withdrew subsidies to agricultural support institutions after 1991. Arguably, the rapid policy shift brought both positive and negative consequences to small scale farmers who had to respond in one way or the other if they were to survive. Consequences of this policy shift are central to this study.

\subsection{Rationale, Focus and Scope}

The rationale of the study was to establish the type, functions and spatial distribution of agricultural support institutions in Central Province of Zambia since independence in 1964 but focusing on the 1980-90 and 1997-2008 periods as case study periods. The 1980-90 period represented the period of controlled economy, while the 1997-2008 period represented the liberalized history of Zambia. The rationale behind the two periods of study was that each period impacted on the agricultural support institutions differently in terms of their capital base, operations and spatiality.

The study focused on small scale farmers because of their prominence in the production of maize which is Zambia's staple food crop and, their weak capital base and vulnerability to policy shifts, especially those to do with input supply, marketing and storage of their produce. Furthermore, the study was limited to three study districts of Central Province-Chibombo, Kapiri Mposhi and Mumbwa Districts.

\section{Materials and Methods Used for the Study}

\subsection{Location of Study Area}

Zambia is located in the southern-central part of Africa between $8^{\circ}$ and $18^{\circ}$ south of the Equator, and between $14^{\circ}$ and $35^{\circ}$ east of the Prime Meridian and comprises 10 provinces (Figure 1). These are Central, Copperbelt, Eastern, Luapula, Lusaka, Northern, North-western, Southern, Muchinga and Western Province. Central Province is located between latitudes $12^{\circ} 4^{\prime}$ and $15^{\circ} 45^{\prime}$ south, longitudes $25^{\circ} 11^{\prime}$ and $31^{\circ} 30^{\prime}$ East (Table 1, Figures 1). Table 1 provides a summary of the physical and socio-economic characteristics of the study area.

While the current study looked at agricultural support institutions existing in the whole country over time, it gave a special focus on Central Province in order to easily compare institutions during the 1980-90 and 1997-2008 periods. Central Province was selected because it is largely an agricultural area where institutions of this nature are evident in the daily lives of people. The selected province is located between the provinces of Eastern, Lusaka, Northern, North-western, Southern and Western (Figure 1). Within Central Province the study limited itself to Chibombo, Kapiri Mposhi and Mumbwa Districts for purposes of making the investigation manageable. These districts formed a 50 percent proportional representation of the total number of districts in the province. The districts were selected on the basis of their varying degrees of agricultural activities, location and accessibility using purposeful sampling. 


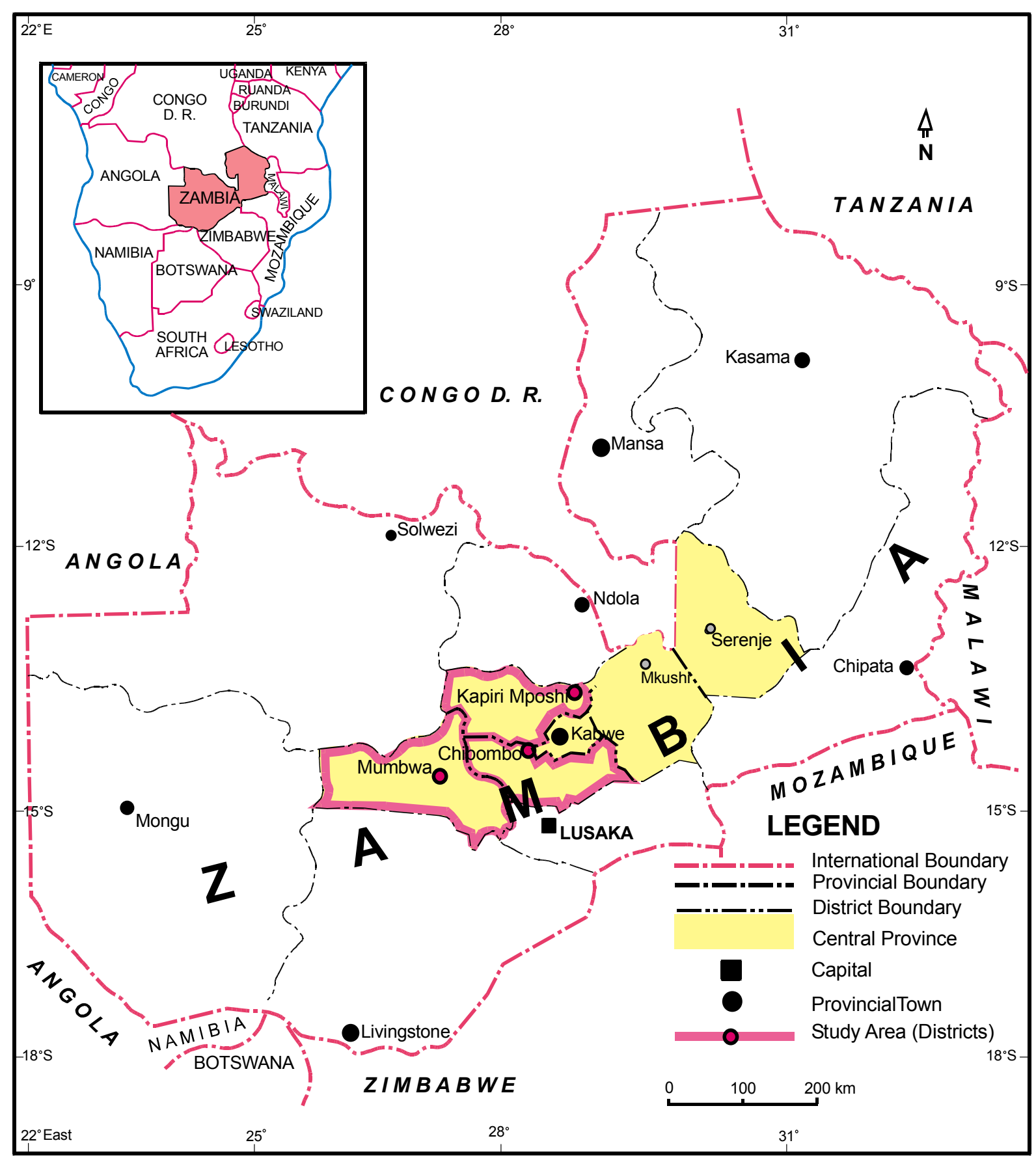

Figure 1. Location of study area 
Table 1 . Summary of physical and socio-economic characteristics of the study area

\begin{tabular}{|c|c|c|c|c|c|c|c|c|c|}
\hline \multicolumn{2}{|l|}{ Characteristics } & \multicolumn{2}{|c|}{ Central Province } & \multicolumn{2}{|c|}{ Chibombo } & \multicolumn{2}{|c|}{ Kapiri Mposhi } & \multicolumn{2}{|c|}{ Mumbwa } \\
\hline \multirow{2}{*}{ Location } & Latitude & $12^{\circ} 04^{\prime} \mathrm{S}$ & $15^{\circ} 45^{\prime} \mathrm{S}$ & $14^{\circ} 40^{\prime} \mathrm{S}$ & $15^{\circ} 25^{\prime} \mathrm{S}$ & $13^{\circ} 45^{\prime} \mathrm{S}$ & $14^{\circ} 50^{\prime} \mathrm{S}$ & $14^{\circ} 10^{\prime} \mathrm{S}$ & $15^{\circ} 36^{\prime} \mathrm{S}$ \\
\hline & Longitude & $25^{\circ} 11^{\prime} \mathrm{E}$ & $31^{\circ} 30^{\prime} \mathrm{E}$ & $27^{\circ} 10^{\prime} \mathrm{E}$ & $29^{\circ} 00^{\prime} \mathrm{E}$ & $26^{\circ} 50^{\prime} \mathrm{E}$ & $28^{\circ} 40^{\prime} \mathrm{E}$ & $25^{\circ} 20^{\prime} \mathrm{E}$ & $27^{\circ} 57^{\prime} \mathrm{E}$ \\
\hline \multicolumn{10}{|c|}{ Physical Features } \\
\hline Agro-ecological region & & \multicolumn{2}{|c|}{ Region B } & \multicolumn{2}{|c|}{ Region B } & \multicolumn{2}{|c|}{ Region $\mathrm{B} / \mathrm{C}$} & \multicolumn{2}{|c|}{ Region B } \\
\hline Soils & & \multicolumn{2}{|c|}{$\begin{array}{l}\text { well-drained acrisol, } \\
\text { luvisol-Phaeozem and } \\
\text { arenosol soils }\end{array}$} & \multicolumn{2}{|c|}{$\begin{array}{l}\text { well-drained acrisol, } \\
\text { luvisol-Phaeozem and } \\
\text { arenosol soils }\end{array}$} & \multicolumn{2}{|c|}{$\begin{array}{l}\text { well-drained acrisol, } \\
\text { luvisol-Phaeozem and } \\
\text { arenosol soils }\end{array}$} & \multicolumn{2}{|c|}{$\begin{array}{l}\text { well-drained acrisol, } \\
\text { luvisol-Phaeozem and } \\
\text { arenosol soils }\end{array}$} \\
\hline Vegetation & & \multicolumn{2}{|c|}{$\begin{array}{l}\text { Open woodland and } \\
\text { savannah grassland }\end{array}$} & \multicolumn{2}{|c|}{$\begin{array}{l}\text { open woodland and } \\
\text { savannah grassland }\end{array}$} & \multicolumn{2}{|c|}{$\begin{array}{l}\text { open woodland and } \\
\text { savannah grassland }\end{array}$} & \multicolumn{2}{|c|}{$\begin{array}{l}\text { open woodland and } \\
\text { savannah grassland }\end{array}$} \\
\hline \multirow[t]{2}{*}{$\begin{array}{l}\text { Climate } \\
\text { (Tropical savannah } \\
\text { climate) } \\
\text { Seasons: Cool dry, hot } \\
\text { dry, hot wet seasons. }\end{array}$} & Rain & & & \multicolumn{2}{|c|}{$\begin{array}{l}\text { Medium } \\
\text { 900-1200 mm }\end{array}$} & \multicolumn{2}{|c|}{$\begin{array}{l}\text { Medium areas in south } \\
(900-1200 \mathrm{~mm}) \text { and } \\
\text { central, and high in } \\
\text { north } \\
\text { (Above } 1200 \mathrm{~mm})\end{array}$} & \multicolumn{2}{|c|}{$\begin{array}{l}\text { Medium } \\
(900-1200 \mathrm{~mm})\end{array}$} \\
\hline & $\begin{array}{l}\text { Temp } \\
{ }^{\circ} \mathrm{C}\end{array}$ & \multicolumn{2}{|c|}{ Cool to hot } & \multicolumn{2}{|c|}{ Cool to hot } & \multicolumn{2}{|c|}{ Cool to hot } & \multicolumn{2}{|c|}{ Cool to hot } \\
\hline \multicolumn{10}{|c|}{ Social-economic characteristics } \\
\hline \multirow[t]{3}{*}{ Roads } & Dust & Numerou & & Numerou & & Numerol & & Numerou & \\
\hline & Gravel & Numerou & & Numerou & & Numerol & & Numerou & \\
\hline & Tarred & $\begin{array}{l}\text { Great No } \\
\text { Great We } \\
\text { Road( Lu }\end{array}$ & Road & $\begin{array}{l}\text { Great No } \\
\text { Great We } \\
\operatorname{Road}(\mathrm{Lu}\end{array}$ & Road & Great $\mathrm{No}$ & h Road & $\begin{array}{l}\text { Great We } \\
\operatorname{Road}(\mathrm{Lu}\end{array}$ & ka-Mongu) \\
\hline Rail & & Livingsto & e-Copperbelt & Livingsto & -Copperbelt & Livingst & e-Copperbelt & & \\
\hline & & $\begin{array}{l}\text { Tanzania- } \\
\text { (TAZAR }\end{array}$ & ambia & & & $\begin{array}{l}\text { Tanzania } \\
\text { (TAZAR }\end{array}$ & ambia & & \\
\hline Population & Rural & &, 202 & & 657 & & 533 & & 2,912 \\
\hline & Urban & & 3,055 & & 55 & & 19 & & 949 \\
\hline & Total & & 2,257 & & 612 & & 4,752 & & 8,861 \\
\hline Livelihood activities & $\begin{array}{l}\text { Rural } \\
\text { (only) }\end{array}$ & $\begin{array}{l}\text { Farming- } \\
\text { Commerc }\end{array}$ & nall scale \& & $\begin{array}{l}\text { Farming- } \\
\text { Commerc }\end{array}$ & all scale \& & $\begin{array}{l}\text { Farming } \\
\text { Commer }\end{array}$ & $\begin{array}{l}\text { mall scale \& } \\
\text { al }\end{array}$ & $\begin{array}{l}\text { Farming- } \\
\text { Commerc }\end{array}$ & nall scale \& \\
\hline & & Fishing & & Fishing & & Fishing & & Fishing & \\
\hline & & Lumberin & & Lumberin & & Lumberi & & Lumberin & \\
\hline & & Hunting & & & & & & Hunting & \\
\hline & & Mining & & & & Mining & & Mining & \\
\hline & & Education & & Educatior & & Educatio & & Education & \\
\hline & & Health & & Health & & Health & & Health & \\
\hline & & Agro-pro & essing & Agro-pro & ssing & Agro-pro & essing & Agro-pro & essing \\
\hline & & Agro-mar & eting & Agro-ma & eting & Agro-ma & reting & Agro-mar & eting \\
\hline
\end{tabular}

Source: Bwalya et al. (1997); CSO (2003); GRZ [soil map], 1986; Meteorological Department 2000.

NB: Region A: Low rainfall region; Region B: Medium rainfall; Region C: High rainfall. 


\subsection{Methods}

(a) Types of data

(i) Secondary data

Secondary data about agricultural support institutions, agricultural policies and number of small scale farmers was obtained from various documented sources, such as old and new maps, various books, journals, newspapers and other written sources.

(ii) Primary Data

Primary data collected for this study included the types of institutions in the study area, changes (lack of changes) that have taken place in the institutional support network in terms of institutions responsible for giving loans, seed, implements, storage, extension services and marketing and their spatiality.

(b) Methods of collecting primary data

\subsubsection{Questionnaires}

\section{(a) Questionnaire for Cooperatives}

Questionnaire 1 was aimed at the members of the Cooperative Societies and their leaders. As a whole, 226 cooperative societies ( $20 \%$ of 1,132 Cooperative Societies) randomly received this questionnaire. Thus, 96 Cooperatives from Chibombo, 77 Cooperatives from Kapiri Mposhi and 53 Cooperatives from Mumbwa were randomly sampled for the study. Membership of individual cooperatives varied greatly. However, the general membership ranged between 10 and 46. It was also noted that the majority of members in the cooperatives were women but most leadership positions were held by men. The study involved a total of 1,367 small scale farmers.

Through Questionnaire 1, primary information about agricultural transformations and spatial patterns for the 1980-1990, and 1997-2008 periods was collected.

(b) Questionnaire for the Ministry of Agriculture Officials

Questionnaire 2 was distributed to three District Agricultural Coordinators (DACOs), three Senior Agricultural Officers (SAOs), three District Cooperative officers and ten Block Extension officers (BEOs). The DACOs, SAOs and DCOs were purposely sampled because of their number and strategic information which they held. Three BEOs (50\% sample) were randomly selected in Chibombo (Chibombo, Chisamba and Keembe farming blocks) and Kapiri Mposhi (Chipepo, Lunchu and Mulungushi farming blocks) Districts, and four BEOs (50\% sample) were selected randomly in Mumbwa District heading Kapyanga, Mukulaikwa, Mumbwa Central and Nambala farming blocks. These government officers provided information about the types, functions, spatiality and transformations of agricultural support institutions in their areas for the 1980-90 and 1997-2008 periods.

(c) Questionnaire for the Zambia Farmers Union and other Organizations

Through Questionnaire 3, the researcher intended collecting general information about the trends unfolding in the three districts. Such information was largely expected to cover the effects of agricultural transformation on institutional arrangements. Since these officials are able to read and write, they filled in the questionnaires on their own.

\subsubsection{Focus Group Discussions (FGD)}

Each FGD was based on a prepared interview schedule. Focus Group Discussions (FGDs) were used for this study as a source of supplementary information to Questionnaire 1 and 2. Such discussions were held where leaders Cooperative Societies were willing and able to mobilize their members for such a venture. In areas where cooperative leaders and the researcher could not manage to bring farmers together no FGDs were held.

A total of three FGDs were conducted in Chibombo district (two Focus Group Discussions in Chibombo Farming block and one FGD in Keembe Farming block). The three Focus Group Discussions had a gender and age segregation. One FGD was for women, the second for men and the third one was for youths. The separation of groups permitted each unit to freely contribute to the discourse without any intimidation from members of the opposite sex. Kapiri Mposhi and Mumbwa Districts had one FGD each - one in Mulungushi Farming Block of Kapiri Mposhi district and another one in Mumbwa Central Farming Block of Mumbwa district. The five FGD Schedules were conducted in Lenje or Tonga languages. This was done in order to obtain as much recollected information about spatial patterns for the 1980-90 and 1997-2008 periods as possible. In Chibombo district one FGD comprised 18 cooperative members (women), second FGD had eight men while the third one comprised 23 youths (14 young women and 9 men). The FGD held in Kapiri Mposhi had 37 members (20 women and 17 men-each group interviewed alone) while the FGD held in Mumbwa had 22 members only (15 women and 7 
men-these were equally interviewed separately).

\subsubsection{Observations}

Observations were used both as a tool of research in itself and to verify certain information collected through questionnaires or FGDs. The researcher and the assistants made observations about agricultural support institutions as they went round meeting cooperative members, government officials and other people. Some notable observations made included hybrid maize seed poster advertisements placed by some seed companies at the edge of fields to show how good the varieties were for given conditions as opposed to others. Names of some seed companies were also written in bold letters accompanied with drawings of big maize cobs on retail outlets as another way to win customers (Plate 1).

Plate 1a illustrates an advertisement used to win seed buyers. Plate $1 \mathrm{~b}$ showed a maize field with a ZAMSEED poster. The two photographs were taken during the observation tour of the study area in Chibombo, Kapiri Mposhi and Mumbwa districts.

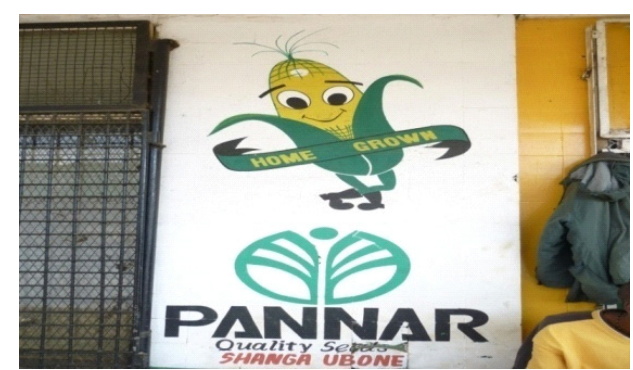

(a)

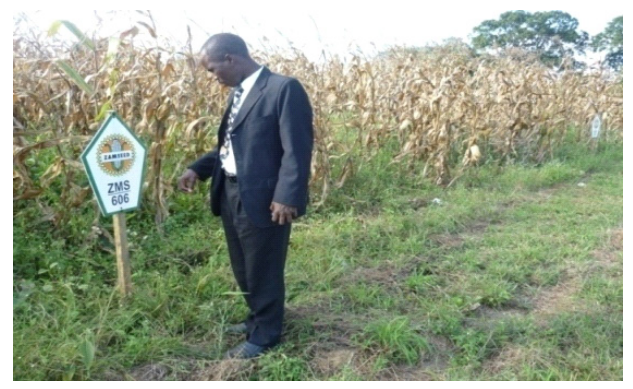

(b)

Plate 1. (a) Pannar advertisement on a wall in Kapiri Mposhi, 2008. (b) ZAMSEED advertisement by Maize field in Chibombo, 2005

\subsubsection{Sampling Frame}

(1) Nature of Sampling Frames

This study adopted a multi faceted sampling frame. It used a frame for Cooperative Societies, a frame for officers in the Ministry of Agriculture, and a frame for the Zambia Farmers Union and non governmental organizations operating in the three districts.

\section{(a) Sampling Frame for Cooperative Societies}

Registers maintained by Block Extension Officers, Cooperative officers and District Agricultural Coordinators were used as a basis for the frame for Cooperative Societies. At commencement of the fieldwork there were 481 registered cooperatives in Chibombo District, 383 in Kapiri Mposhi District and 268 in Mumbwa District.

(b) Sampling Frame for Officers in the Ministry of Agriculture and Cooperatives

The list of officers interviewed was obtained from the Ministry of Agriculture and Cooperatives in each of the three study districts. The list included the three DACOs, three SAOs, three DCOs, three BEOs from Chibombo, three Block Extension Officers from Kapiri Mposhi, and four from Mumbwa Districts.

\section{(c) Sampling Frame for ZNFU and Non Governmental Organizations}

This frame covered officers for the Zambia National Farmers Union, Agricultural Support Programme (ASIP), Plan Zambia and Africare officers operating in the study areas. Since they were few all of them that were found in the study areas at the time of the fieldwork were interviewed.

\subsubsection{Sampling Unit}

The farming block was used as the sampling unit for this study. The sample of farming blocks comprised three in Chibombo (Chisamba, Chibombo, and Keembe) and Kapiri Mposhi districts (Chipepo, Lunchu and Mulungushi), and four farming blocks in Mumbwa district (Kapyanga, Mukulaikwa, Mumbwa Central and Nambala), representing $50 \%$ of Farming blocks in each district. The selection of farming blocks took into account agricultural activities in each farming area, accessibility of each farming block and availability of transport networks. Between 20\% and 50\% Agricultural Camps in each Farming Block were used as the secondary 
sampling unit for purposes of selecting Cooperative Societies at the village level.

\subsubsection{Sample Selection and Structure}

\section{(a) Cooperative Societies}

Table 2 shows the sample structure of the study area. The statistics below were obtained from the Cooperative Officers in the study districts. The district sample size was calculated at $20 \%$ of the total number of registered Cooperatives $(20 / 100 \times 1132=226)$. The sample size of Farming Blocks was calculated on the basis of the number of existing cooperatives in the block in relation to the overall district sample size (Table 2). Thus, farming blocks with a higher number of cooperatives contributed a bigger number of sampled cooperatives to make the district sample size.

Table 2. Sample selection of cooperatives in the study districts and farming blocks

\begin{tabular}{lllcc}
\hline District & \multicolumn{2}{c}{$\begin{array}{c}\text { Cooperative Sample Size Per } \\
\text { Farming Block }\end{array}$} & $\begin{array}{c}\text { Sample Size of } \\
\text { District }\end{array}$ & $\begin{array}{c}\text { Total Cooperatives in Sampled } \\
\text { Farming Blocks }\end{array}$ \\
\hline \multirow{3}{*}{ Chibombo } & Chibombo & $180 / 321 \times 96=54$ & $20 / 100 \times 48$ & \\
& Chisamba & $54 / 321 \times 96=16$ & $=96$ & 321 \\
& Keembe & $87 / 321 \times 96=26$ & & \\
\hline \multirow{2}{*}{ Kapiri } & Lunchu & $32 / 190 \times 77=13$ & $20 / 100 \times 268$ & \\
Mposhi & Mulungushi & $56 / 190 \times 77=23$ & $=77$ & \\
& Chipepo & $102 / 190 \times 77=41$ & & \\
\hline \multirow{4}{*}{ Mumbwa } & Kapyanga & $15 / 139 \times 53=6$ & & \\
& Mukulaikwa & $24 / 139 \times 53=9$ & $20 / 100 \times 268$ \\
& Mumbwa Central & $56 / 139 \times 53=21$ & $=53$ & \\
\hline Total & Nambala & $44 / 139 \times 53=17$ & & $\mathbf{7 1 2}$ \\
\hline
\end{tabular}

Source: DACO files (2007) in three study districts.

In order to achieve a fair and proportionate representation, a multi-stage sampling procedure involving random, stratified and systematic methods was adopted for this study. Firstly, the three study districts were sampled from six districts in the province representing a 50\% sample size. Then the study used Farming Blocks and Agricultural Camps. Thirdly, the cooperative population was divided into non-overlapping groups such that $\mathrm{n} 1+$ $\mathrm{n} 2+\mathrm{n} 3+\ldots+\mathrm{ni}=\mathrm{N}$. Then, a random sample of $\mathrm{f}=\mathrm{n} / \mathrm{N}$ was calculated in each stratum to determine the sample fraction, where $\mathrm{f}=$ sample fraction, $\mathrm{n}=$ number of cases in the sample and $\mathrm{N}=$ number of cases in the sampling frame. In order to select the actual cooperatives in each stratum, computer generated random numbers were used.

(b) Extension Staff

All extension officers of the Ministry of Agriculture and Cooperatives present in the sampled districts and blocks were picked for the study (three DACOs, SAOs, DCOs and the ten BEOs for Chibombo, Kapiri Mposhi and Mumbwa districts). This was done because the number of officers in each district and/or block was small and they are custodians of very important information which was needed for the study.

\subsubsection{Fieldwork}

Fieldwork activities took place between October, 2008 and August 2010, mainly during the dry season when roads were fairly passable. Very limited fieldwork was undertaken during the rainy season due to poor roads except in circumstances where the researcher visited selected farming areas which were along main roads. Table 3 and Figure 2 gives a summary of the number of questionnaires distributed to respondents and those eventually returned to the researcher. 
Table 3. Cooperative societies questionnaire schedule

\begin{tabular}{lcccc}
\hline District & Sample Size & $\begin{array}{c}\text { Number of returned } \\
\text { questionnaires }\end{array}$ & $\begin{array}{c}\text { Number of questionnaires } \\
\text { not returned }\end{array}$ & $\begin{array}{c}\text { Success } \\
\text { percentage }\end{array}$ \\
\hline Chibombo & 96 & 71 & 25 & 74 \\
Kapiri Mposhi & 77 & 48 & 29 & 62 \\
Mumbwa & 53 & 49 & 4 & 93 \\
Total & 226 & 168 & 58 & 74 \\
\hline
\end{tabular}

Source: Fieldwork.

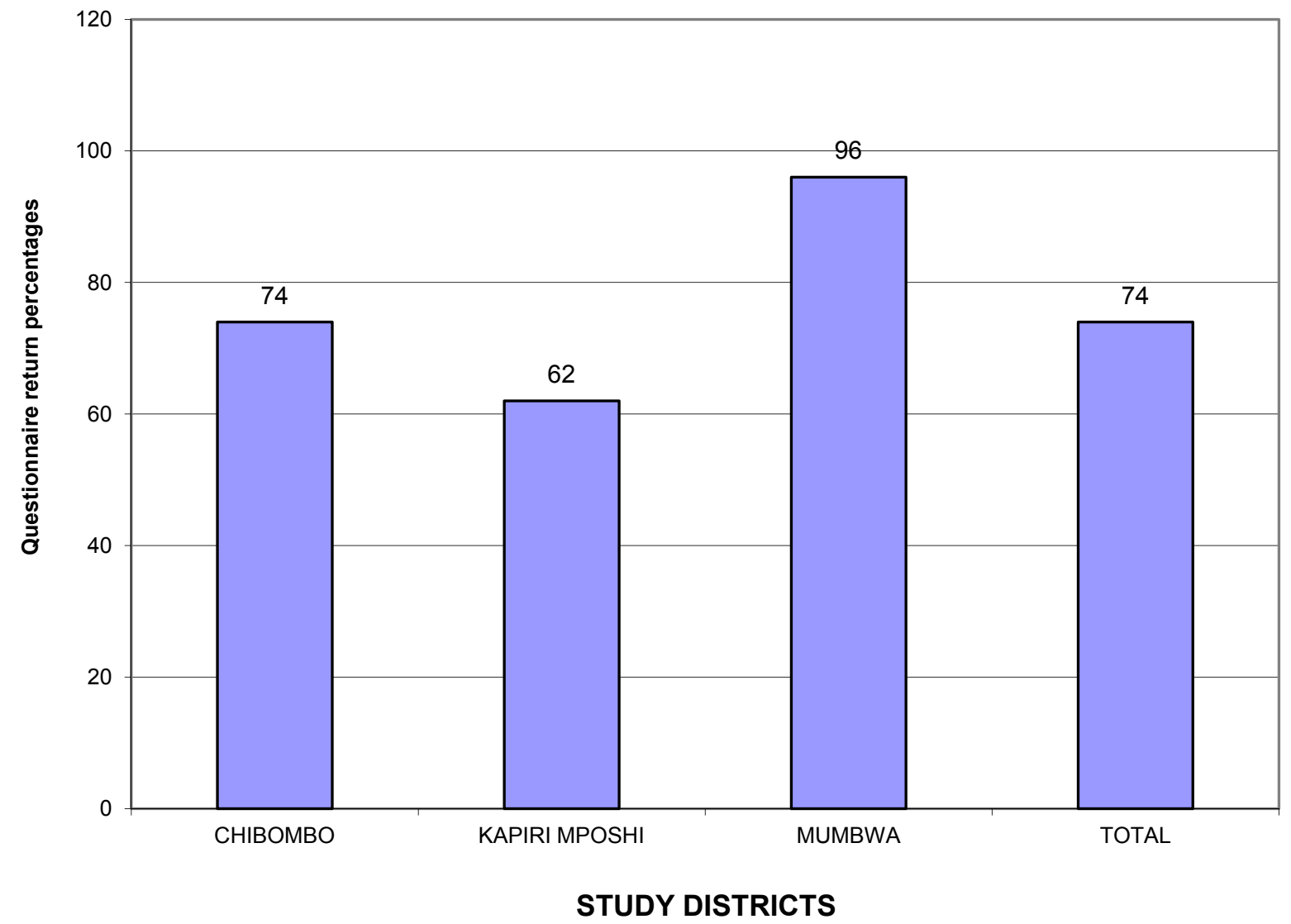

Figure 2. Questionnaire administration analysis

\section{Results and Discussion}

\subsection{Characteristics of Agricultural Support Institutions}

Table 4 gives a summary of characteristics of agricultural support institutions. The summary given in the table points out stakeholders, type of institution, services provided and target group. 
Table 4. Characteristics of agricultural support institutions

\begin{tabular}{|c|c|c|c|}
\hline Major stakeholder & Name of institution & Services provided & Target group \\
\hline Farmers & $\begin{array}{l}\text { Credit Union and Savings } \\
\text { Association } \\
\text { (CUSA) }\end{array}$ & Cash credit & Small scale farmers \\
\hline \multirow{11}{*}{ Government } & $\begin{array}{l}\text { Agricultural Finance } \\
\text { Corporation (AFE) }\end{array}$ & Cash credit & Large scale farmers \\
\hline & $\begin{array}{l}\text { Agricultural farming } \\
\text { equipment(AFE) }\end{array}$ & Implements & $\begin{array}{l}\text { Small scale and large } \\
\text { scale farmers }\end{array}$ \\
\hline & Lima Bank & Cash & Small scale farmers \\
\hline & District cooperatives & $\begin{array}{l}\text { Crop marketing and } \\
\text { storage }\end{array}$ & Small scale farmers \\
\hline & $\begin{array}{l}\text { Lint Company of Zambia } \\
\text { (LINTCO) }\end{array}$ & $\begin{array}{l}\text { Cotton chemicals, seed, } \\
\text { marketing }\end{array}$ & Small scale farmers \\
\hline & $\begin{array}{l}\text { National Agricultural } \\
\text { Marketing Board } \\
\text { (NAMBOARD) }\end{array}$ & $\begin{array}{l}\text { Crop marketing and } \\
\text { storage }\end{array}$ & $\begin{array}{l}\text { Small scale and large } \\
\text { scale farmers }\end{array}$ \\
\hline & $\begin{array}{l}\text { Tobacco Board of Zambia } \\
\text { (TBZ) }\end{array}$ & Tobacco & $\begin{array}{l}\text { Small scale and large } \\
\text { scale farmers }\end{array}$ \\
\hline & $\begin{array}{l}\text { Zambia Cooperative } \\
\text { Federation }\end{array}$ & $\begin{array}{l}\text { Crop marketing and } \\
\text { storage, finance. }\end{array}$ & Small scale farmers \\
\hline & $\begin{array}{l}\text { Farmer input support } \\
\text { programme (FISP) }\end{array}$ & $\begin{array}{l}\text { Subsidized hybrid seed } \\
\text { and fertilizer }\end{array}$ & Small scale farmers \\
\hline & $\begin{array}{l}\text { Food Reserve Agency } \\
\text { (FRA) }\end{array}$ & $\begin{array}{l}\text { Crop marketing and } \\
\text { storage }\end{array}$ & $\begin{array}{l}\text { Small scale and large } \\
\text { scale farmers }\end{array}$ \\
\hline & $\begin{array}{l}\text { Ministry of Agricultural } \\
\text { and Cooperatives } \\
(\mathrm{MACO})\end{array}$ & Extension & Small scale farmers \\
\hline $\begin{array}{l}\text { Non governmental } \\
\text { organization }\end{array}$ & & $\begin{array}{l}\text { Extension, small packs of } \\
\text { seed and fertilizer }\end{array}$ & $\begin{array}{l}\text { Vulnerable small scale } \\
\text { farmers }\end{array}$ \\
\hline Private sector & $\begin{array}{l}\text { Pannar, Dunavant, } \\
\text { Cargill, Omnia and } \\
\text { Miombo fertilizers, etc }\end{array}$ & $\begin{array}{l}\text { Hybrid seed of maize, } \\
\text { chemicals \& extension }\end{array}$ & $\begin{array}{l}\text { Small scale farmers and } \\
\text { large scale farmers }\end{array}$ \\
\hline State companies & $\begin{array}{l}\text { Zambia Seed Company } \\
\text { (ZAMSEED) }\end{array}$ & Hybrid seeds & $\begin{array}{l}\text { Small scale and large } \\
\text { scale farmers }\end{array}$ \\
\hline \multirow{2}{*}{ Research } & $\begin{array}{l}\text { Golden Valley Research } \\
\text { Trust (GV) }\end{array}$ & Research, hybrid seeds & $\begin{array}{l}\text { Small scale and large } \\
\text { scale farmers }\end{array}$ \\
\hline & $\begin{array}{l}\text { Mount Makulu Research } \\
\text { Station (MM) }\end{array}$ & Research, hybrid seeds & $\begin{array}{l}\text { Small scale and large } \\
\text { scale farmers }\end{array}$ \\
\hline
\end{tabular}

Source: Fieldwork.

3.1.1 Agricultural Support Institutions before Independence

Agricultural support institutions developed before independence in 1964 are summarized in Table 5. 
Table 5. Agricultural Support Institutions before independence

\begin{tabular}{lll}
\hline Year formed & Institution & Funding \\
\hline 1914 & First cooperative & Settler farmers \\
1936 & Maize Control Board (MCB) & Colonial government \\
1947 & African cooperatives & African farmers \\
1948 & Dept of Marketing and Cooperatives & Colonial government \\
1952 & Eastern Province Agricultural Produce Board (EPAPB) & Colonial government \\
1957 & Federal Grain Marketing Board (FGMB) & Colonial government \\
\hline
\end{tabular}

Source: Chabala and Sakufiwa, 1993

\subsubsection{Agricultural Support Institutions between 1964 and 1973}

At independence in 1964, the government of the Republic of Zambia established its own agricultural support institutions to provide various services to farmers different from those inherited from the previous colonial government. These are given in Table 6. These institutions provided services both for commercial farmers and small scale farmers who were mainly in remote areas of the country.

Table 6. Agricultural support institutions between 1964 and 1973

\begin{tabular}{lll}
\hline $\begin{array}{l}\text { Year } \\
\text { formed }\end{array}$ & Institution & Funding \\
\hline \multirow{3}{*}{1964} & Grain Marketing Board (GMB) and & Government \\
& Agricultural Rural Marketing Board (ARMB) & Government \\
& Southern Province Marketing Union (SPCMU) & Government \\
& Eastern Co-operative Union (ECU)) & Government \\
\hline \multirow{2}{*}{1968} & Land Bank (later changed to Credit Organization of Zambia which also & \\
& was later in years dissolved for Agricultural Finance Company (AFC). & Government \\
\hline 1969 & Later AFC changed into Lima Bank & \\
\hline
\end{tabular}

Source: Fieldwork

\subsubsection{Agricultural Support Institutions after 1973}

Several agricultural support institutions were created by government after the country was turned into a one-party state of controlled planning. These are summarized in Table 7. 
Table 7. Agricultural Support institutions formed after 1973

\begin{tabular}{ll}
\hline Institution & Funding \\
\hline Agricultural Finance Company (AFC) & Government \\
Agricultural Farming Equipment (AFE) & Government \\
Credit Union and Savings Association (CUSA) & Members' subscriptions and government \\
Lint Company of Zambia (LINTCO) & Government \\
Nitrogen Chemicals of Zambia (NCZ) & Government \\
Tobacco Board of Zambia (TBZ) & Government \\
Zambia Cooperative Federation (ZCF) took over functions of & \\
NAMBOARD in 1989 when it was abolished. ZCF operated & Government \\
Provincial and District Cooperatives after 1989 & \\
Zambia Seed Company (ZAMSEED) & Government \\
\hline
\end{tabular}

Source: Literature reviewed.

Mwanza (1992), Chabala and Sakufiwa (1993) and World Bank (1994) have argued that the shortage of qualified and experienced manpower in the post 1973 agricultural support institutions made them operate as social equity institutions tailored towards government political goals rather than businesses with a profit motive. Table 8 and Figure 3 show credit disbursements from two credit organizations between 1984 and 1989. At this time, it must be borne in mind, that these amounts were big sums of money. Similarly, as Chabala and Sakufiwa (1993:37) have pointed out, credit lending at this time suffered very high non-recoveries some of which were as high as $60 \%$ or more at times. Thus, the degree of farmer defaulting was reported to be very high because many farmers, especially peasant farmers, considered loans from government to be annual gifts without any negative consequence.

Further, Klepper states that the government, on its part, "failed to organize and train cadres to work in rural areas and bring to the peasantry ideological training as a complement to putting fertilizers, tractors, and ploughs in their hands" (Klepper, 1979:141).

Table 8. Amounts of credit approved by Lima Bank and ZCF Financial Services - 1983-84 to 1988-89

\begin{tabular}{ccc}
\hline FARMING SEASON & $\begin{array}{c}\text { LIMA BANK } \\
\text { (Zambian Kwacha '000) }\end{array}$ & $\begin{array}{c}\text { ZCF FINANCE SERVICES } \\
\text { (Zambian Kwacha '000) }\end{array}$ \\
\hline $1983 / 84$ & 45,585 & 4,180 \\
$1984 / 85$ & 55,903 & 6,001 \\
$1985 / 86$ & 48,005 & 6,026 \\
$1986 / 87$ & 79,322 & 60,000 \\
$1987 / 88$ & 86,022 & 80,139 \\
$1988 / 89$ & 214,204 & 107,933 \\
\hline
\end{tabular}

Source: Chabala and Sakufiwa (1993:37). 


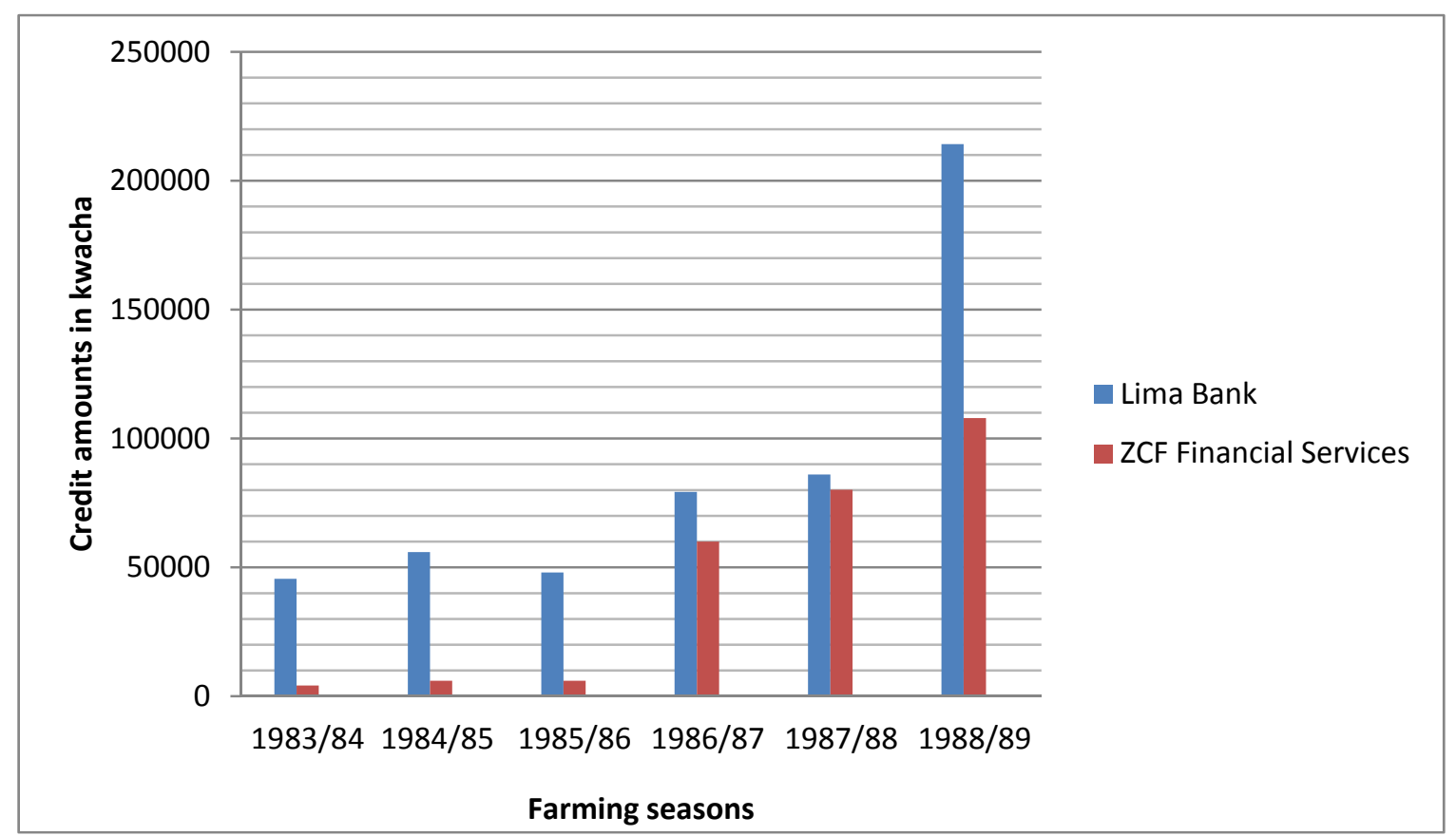

Figure 3. Credit Disbursements to farmers

The culture of not paying back loans affected, directly, both government and agricultural institutions' coffers. Government subsidies to agriculture kept on increasing. In 1979, for example, “... the total subsidy to agriculture, most of which went to NAMBOARD, exceeded K100 million and was about $19 \%$ of the total recurrent government spending" (Mwanza, 1992: 131). These subsidies included meeting the cost of inputs like chemical fertilizers, seed, and funding the credit institutions that gave the small-scale farmers agricultural loans. Table 9 and Figure 4 show the amount of government subsidies, especially for maize, for the period 1980 to 1990.

Table 9. Maize subsidies related to Government budget (recurrent and capital), and budget deficit -1980 to 1990

\begin{tabular}{ccccc}
\hline Year & $\begin{array}{c}\text { GOVT BUDGET } \\
\left(\mathbf{K}^{\prime} \mathbf{M}\right)\end{array}$ & $\begin{array}{c}\text { BUDGET } \\
\text { DEFICIT } \\
\left(\mathbf{K}^{\prime} \mathbf{M}\right)\end{array}$ & $\begin{array}{c}\text { MAIZE } \\
\text { SUBSIDIES } \\
\left(\mathbf{K}^{\prime} \mathbf{M}\right)\end{array}$ & $\begin{array}{c}\text { SUBSIDIES AS \% } \\
\text { OF BUDGET }\end{array}$ \\
\hline 1980 & $1,657.6$ & 160.3 & 154.0 & 9.3 \\
1981 & $1,388.6$ & 155.7 & 87.1 & 6.3 \\
1982 & $1,643.2$ & 658.1 & 138.0 & 8.4 \\
1983 & $1,475.9$ & $8.6 *$ & 124.7 & 8.4 \\
1984 & $1,484.6$ & 284.8 & 81.6 & 5.5 \\
1985 & $2,84.3$ & 280.4 & 134.0 & 6.1 \\
1986 & $5,383.6$ & $1,025.7$ & 565.0 & 10.5 \\
1987 & $5,837.5$ & $2,146.8$ & 638.4 & 10.9 \\
1988 & $8,359.3$ & $1,531.2$ & $1,413.0$ & 16.9 \\
1989 & $9,838.0$ & $3,699.0$ & $1,585.6$ & 16.1 \\
1990 & $24,503.3$ & $2,801.4$ & $3,363.9$ & 13.7 \\
\hline
\end{tabular}

Source: Chabala and Sakufiwa (1993:46).

$\mathrm{K}^{\prime} \mathrm{M}=$ Zambian Kwacha in millions

*No reason is given to explain why the 1983 budget deficit figure of 8.6 came about. 


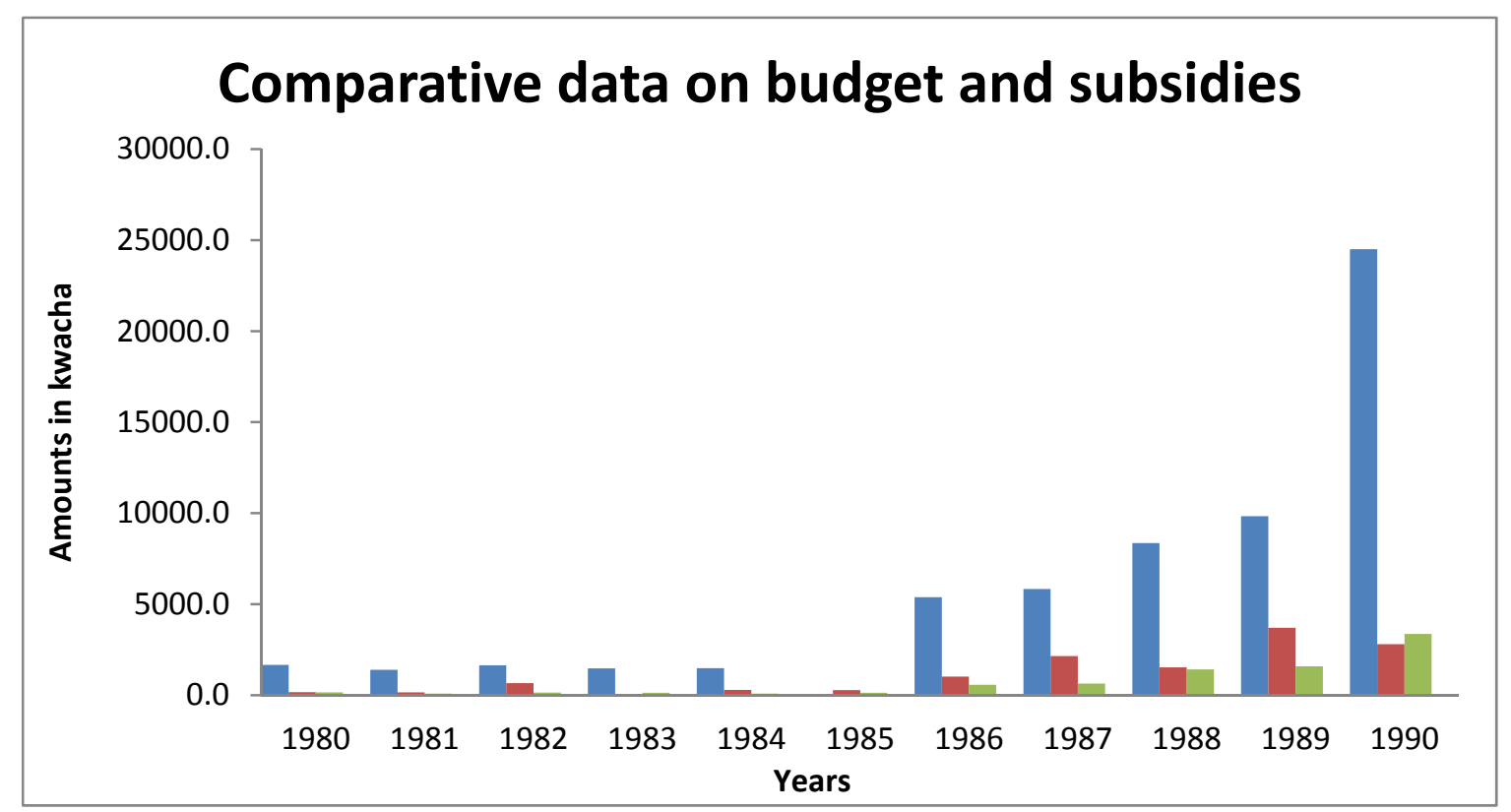

Figure 4. Comparative financial data-budget, subsidies and deficits

Table 10. Existing agricultural support institutions by district in the 1980-90 and 1997-2008 periods

\begin{tabular}{|c|c|c|c|c|}
\hline \multicolumn{5}{|c|}{ Agricultural Support institutions between 1980 and 1990} \\
\hline Institution & Chibombo & Kapiri Mposhi & Mumbwa & Other towns \\
\hline CUSA & Present & Not present & Present & Present \\
\hline Lima bank & Not present & Not present & Present & Present in Kabwe \\
\hline $\begin{array}{l}\text { ZCF Financial } \\
\text { Services }\end{array}$ & Not present & Not present & Not present & Present \\
\hline LINTCO & Present & Present & Present & Present \\
\hline NAMBOARD & Present & Present & Present & Present \\
\hline $\mathrm{NCZ}$ & Not present & Not present & Not present & Present in Kafue \\
\hline ZAMSEED & Present & Not present & Present & Present \\
\hline \multicolumn{5}{|c|}{ Agricultural support institutions between 1997 and 2008} \\
\hline FISP & Present & Present & Present & Present \\
\hline FRA & Present & Present & Present & Present \\
\hline Cargill & Present & Present & Present & Present \\
\hline Clark cotton & Present & Present & Present & Present \\
\hline Dunavant & Present & Present & Present & Present \\
\hline Pannar & Not present & Not present & Not present & Present \\
\hline MRI & Not present & Not present & Not present & Present \\
\hline Pioneer & Not present & Not present & Not present & Present \\
\hline ZAMSEED & Present & Present & Present & Present \\
\hline Miombo & Present & Present & Present & Present \\
\hline Omnia & Present & Present & Present & Present \\
\hline GV & Present & Not present & Not present & Not present \\
\hline MM & Not present & Not present & Not present & Present \\
\hline
\end{tabular}

Source: Fieldwork. 
3.1.4 Agricultural Support Institutions (systems) in Central Province of Zambia between 1980-90 and 1997-2008

Between 1980 and 1990, CUSA, Lima Bank and ZCF Financial Services provided farmers with cash loans; NCZ supplied chemical fertilizers; MACO gave extension services; NAMBOARD, District and Provincial Cooperatives supplied commodity inputs and bought produce; ZAMSEED provided farmers with hybrid seed; LINTCO supplied inputs and bought cotton; AFE was the source of agricultural equipment (Table 10). These services were provided in Central Province as well as the rest of Zambia both in urban and rural areas. Apart from AFE, Lima Bank, ZCF Financial Services and NCZ which had no infrastructure in farming areas, the other organizations were well represented in all areas. They had an elaborate and widely spread out network throughout the farming community.

Their network was widely spread out both as a way to serve the farming community better and to implement government policy. They had to implement the policy of the government because it controlled and funded their operations (Mwanza, 1992). As Mwanza (1992) and other scholars have argued, political interference made these institutions not make independent economic and operational decisions leading to poor management, profitability and viability. Thus, owing to the government agricultural policy of uniformity national agricultural support institutions also existed in Central Province, just like in other provinces.

\subsubsection{Spatial Analysis of Agricultural Support Institutions}

Between 1980 and 1990 it was government policy to position an agricultural support institution in each farming area within a range of 5 kilometers (DACO-Chibombo, 2008)-Figure 5. The agricultural support institutions, financed by government, had the mandate of providing inputs, purchase produce from small scale farmers and act as paying depots. As much as possible such infrastructure was elaborately distributed in each farming district without any segregation. Such an ambitious strategy helped to provide a generally uniform infrastructural landscape throughout the study areas and, helped to enhance positive crop farming.

After 1997 the government policy of subsidies was discontinued and many agricultural institutions collapsed. Soon after, new privately owned, funded and controlled firms emerged to fill the vacuum left bebind by the previous organizations (Figure 5). The new private institutions did not have an equal financial ability to set up an elaborate field infrastructure like was the case between 1980-90 period. Though more self-sustaining, the privately funded agricultural support network was limited in its spatiality. Mainly, the new infrastructure was located along main communication roots and near urban centers. Such a development was inappropriate and inadequate for the large population of small scale farmers who where more spatially more widely distributed. The resulting consequence of a limited field infrastructure was an increase in the cost of inputs, transport and to some extent, complete loss of markets. As a ripple effect crop farming diminished. For instance, the production of crops such as sunflower declined markedly. But new crops and farming practices emerged, too. Small scale farmers started to grow cash crops which were previously not common. Crops which emerged in this category included traditional egg plants (impwa), vegetables and water melons. Farming practices evolved, too. Conservation farming, agro forestry and seasonal irrigation were some of the new innovations which became common after 1997 as coping strategies to mitigate loss of income. 


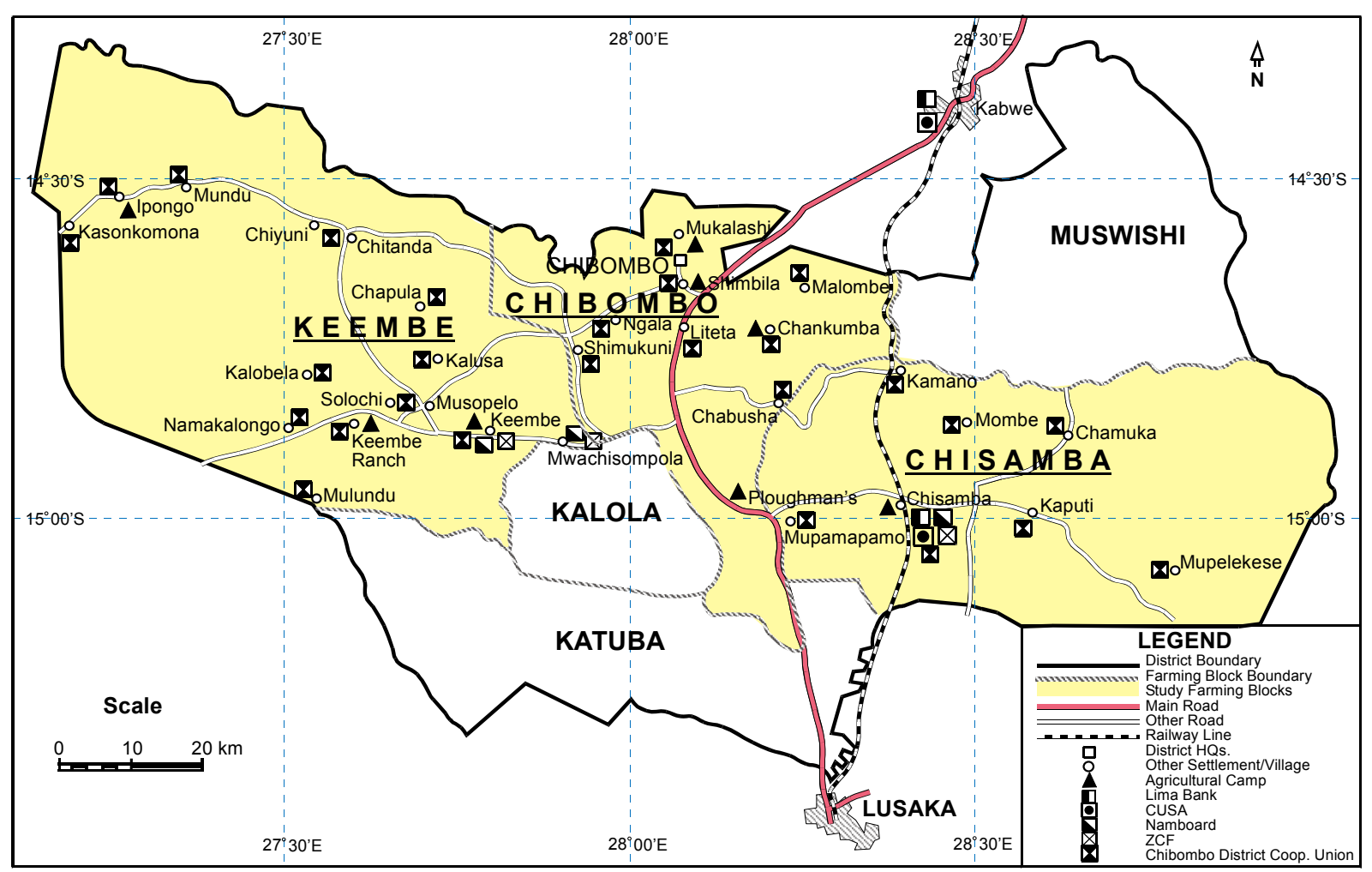

Figure 5. Agricultural support institutions in Chibombo District, 1980-90

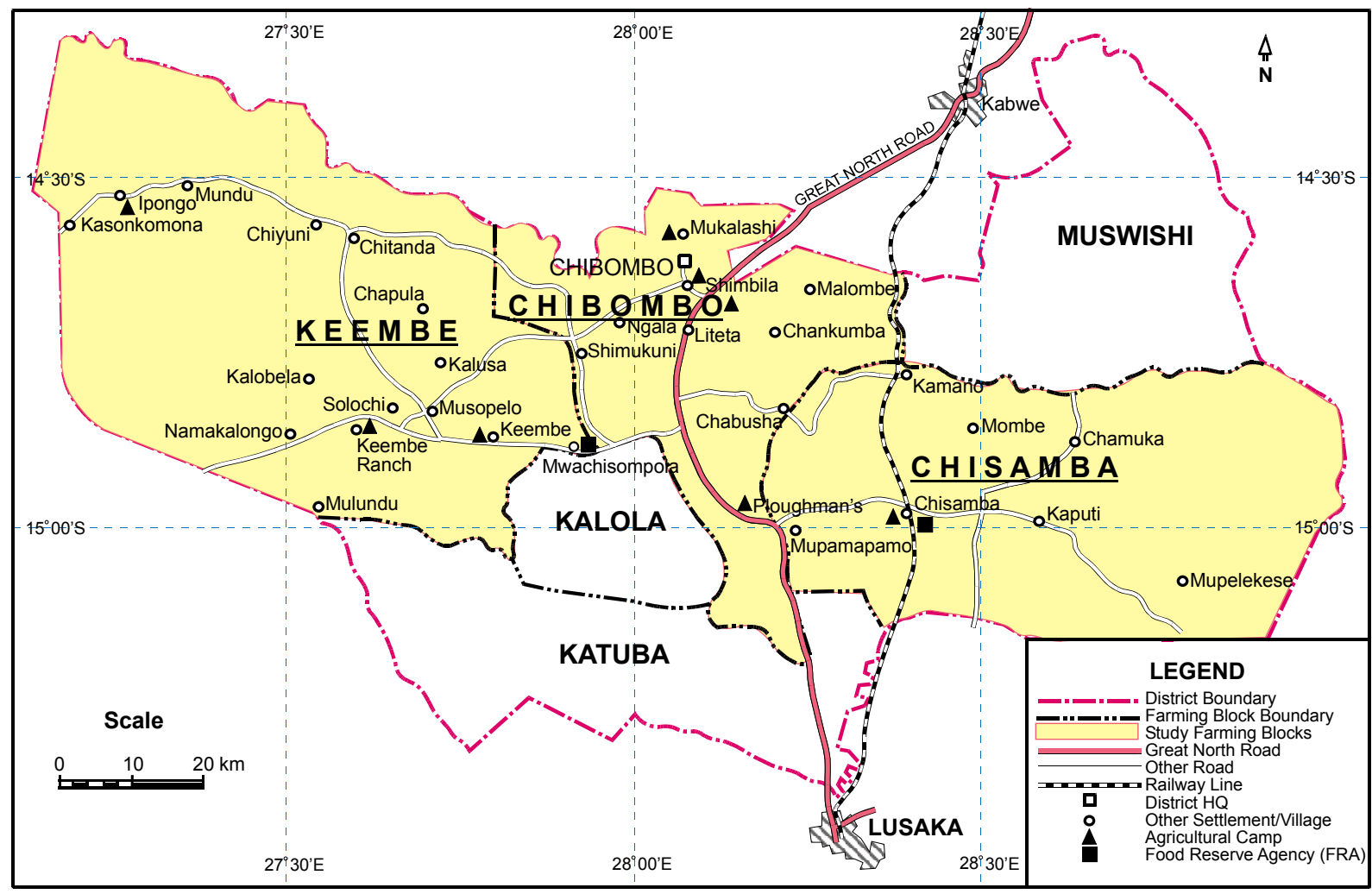

Figure 6. Agricultural support institutions in Chibombo District, 1997-2008

The institutional spatial analysis for the three districts is summarized in Table 11, 12 and 13 below. 
Table 11. Agricultural support institutions distribution pattern in Chibombo District

\begin{tabular}{lccc}
\hline \multirow{2}{*}{ Institutions } & \multicolumn{3}{c}{ Farming blocks in Chibombo } \\
\cline { 2 - 4 } & Chibombo & Chisamba & Keembe \\
\hline CUSA & 1 & $\mathbf{1 9 8 0 - 9 0 ~ p e r i o d ~}$ & 1 \\
Lima bank & 0 & 1 & 0 \\
NCZ & 0 & 1 & 0 \\
NAMBOARD & 3 & 0 & 3 \\
ZCF & 2 & 3 & 2 \\
ZAMSEED & 2 & 0 \\
Total & 0 & 0 & $\mathbf{6}$ \\
\hline & $\mathbf{6}$ & $\mathbf{7}$ & 1 \\
\hline Cargill & & $\mathbf{1 9 9 7 - 2 0 0 8}$ & 1 \\
Clark cotton & 1 & 0 & 2 \\
Dunavant & 2 & 0 & 3 \\
FISP Program & 1 & 0 & 3 \\
FRA & 3 & 3 & 1 \\
GV & 3 & 3 & 0 \\
MM & 1 & 0 & 2 \\
MRI & 0 & 0 & 2 \\
Pannar & 1 & 2 & 1 \\
SEEDCO & 1 & 2 & $\mathbf{1 8}$ \\
ZAMSEED & 1 & 2 & \\
Total & 2 & 3 & \\
\hline
\end{tabular}

Source: Fieldwork, 2008.

Key: $0=$ Non existent; $1=$ Limited distribution; $2=$ Moderate distribution; $3=$ Widely distributed.

Table 12. Agricultural support institutions distribution pattern in Kapiri Mposhi District

\begin{tabular}{lccc}
\hline Institutions & \multicolumn{3}{c}{ Farming blocks in Kapiri Mposhi } \\
\cline { 2 - 4 } & Chipepo & Lunchu & Mulungushi \\
\hline CUSA & 1 & $1980-90$ period & 2 \\
Lima bank & 0 & 0 & 0 \\
NCZ & 0 & 0 & 0 \\
NAMBOARD & 3 & 0 & 3 \\
ZCF & 2 & 3 & 2 \\
ZAMSEED & 0 & 2 & 0 \\
Total & $\mathbf{6}$ & 0 & $\mathbf{7}$ \\
\hline & & $\mathbf{5}$ & 1 \\
\hline Cargill & 1 & $\mathbf{1 9 9 7 - 2 0 0 8}$ & 1 \\
Clark cotton & 1 & 0 & 2 \\
Dunavant & 2 & 1 & 3 \\
FISP Program & 3 & 2 & 3 \\
FRA & 3 & 3 & 0 \\
GV & 0 & 3 & 0 \\
MM & 0 & 0 & 0 \\
MRI & 0 & 0 & 0 \\
Pannar & 1 & 0 & 1 \\
SEEDCO & 1 & 0 & 1 \\
ZAMSEED & 1 & 1 & $\mathbf{1 2}$ \\
Total & $\mathbf{1 3}$ & 1 & \\
\hline
\end{tabular}

Source: Fieldwork, 2008.

Key: $0=$ Non existent; $1=$ Limited distribution; $2=$ Moderate distribution; $3=$ Widely distributed. 
Table 13. Agricultural support institutions distribution pattern in Mumbwa District

\begin{tabular}{|c|c|c|c|c|}
\hline \multirow[t]{2}{*}{ Institutions } & \multicolumn{4}{|c|}{ Farming blocks in Mumbwa District } \\
\hline & Kapyanga & Mumbwa Central & Mukulaikwa & Nambala \\
\hline \multicolumn{5}{|c|}{$1980-90$ period } \\
\hline CUSA & 2 & 3 & 1 & 2 \\
\hline Lima bank & 0 & 1 & 0 & 0 \\
\hline $\mathrm{NCZ}$ & 0 & 0 & 0 & 0 \\
\hline NAMBOARD & 3 & 3 & 3 & 3 \\
\hline $\mathrm{ZCF}$ & 2 & 2 & 2 & 2 \\
\hline ZAMSEED & 0 & 0 & 0 & 0 \\
\hline Total & 7 & 9 & 6 & 7 \\
\hline \multicolumn{5}{|c|}{$1997-2008$} \\
\hline Cargill & 2 & 2 & 2 & 2 \\
\hline Clark cotton & 3 & 3 & 3 & 3 \\
\hline Dunavant & 3 & 3 & 3 & 3 \\
\hline FISP Program & 3 & 3 & 3 & 3 \\
\hline FRA & 3 & 3 & 3 & 3 \\
\hline GV & 0 & 0 & 0 & 0 \\
\hline MM & 0 & 0 & 0 & 0 \\
\hline MRI & 1 & 1 & 1 & 1 \\
\hline Pannar & 2 & 2 & 2 & 1 \\
\hline SEEDCO & 1 & 1 & 1 & 1 \\
\hline ZAMSEED & 2 & 2 & 2 & 2 \\
\hline Total & 20 & 20 & 20 & 19 \\
\hline
\end{tabular}

Source: Fieldwork, 2008.

Key: $0=$ Non existent; $1=$ Limited distribution; $2=$ Moderate distribution; $3=$ Widely.

A close examination of the spatial statistics per district in the above tables reveals that government supported institutions tended to be more widely distributed than private institutions, which were many but concentrated in fewer areas only. For example, during the 1980-90 period NAMBOARD, ZCF and CUSA were more widely distributed than the other institutions. Lima bank was the least distributed despise offering a very important service. This may be attributed to the sensitive nature of money. Furthermore, the data suggests that the more access an area was the more agricultural support institutions it had. This argument is supported by the statistics for farming blocks such as Mumbwa Central and Chibombo. In more agriculturally active farming areas such as Chisamba, more support institutions existed, too.

Between 1997 and 2008, FISP and FRA dominated other institutions in their geographical distribution. This may be attributed to the nature, importance and cost of services offered. As reported earlier, FISP provided subsidized maize seed and eight bags of fertilizer (four basal and four top dressing fertilizer) at a markedly reduced price. Because of a weak capital base and, perhaps due to the persistent dependency syndrome of small scale farmers on government support, any institution providing a relatively cheap service enjoyed wide acceptability against those services in which farmers needed to pay a full market price. Additionally, hybrid seed companies such as MRI and Pannar had a better geographical distribution than research stations. This trend may show the level of appreciation of the role of research among small scale farmers.

On a district-by-district comparison, Mumbwa District scored more than Chibombo and Kapiri Mposhi districts. Mumbwa's higher score on the presence of agricultural support institutions can be attributed to a high level of agricultural activities taking place in the area, especially for cotton. Chibombo District came second while Kapiri Mposhi was least. The Mumbwa-Chibombo-Kapiri Mposhi regressive sequence is proportionately related to the level of farming activities in each district.

Comparatively with other parts of the world, Jacobsen et al. (1995), Gerrard et al. (1994), Kokwe (1997), Mwanza (1992) and World Bank (1994) have all argued that trends of such institutional support in farming areas, and the general transformations taking place in the three study districts happen in all adjusting economies in the world. These scholars have made specific reference to countries in the region such as Zimbabwe and Tannzania; and Argentina and Chile in South America. It is further argued that the same effects of institutional changes on crop production taking place in this part of the world are being experienced by other countries within and outside the 
Southern African region. Differences may emerge because of cultural, political and environmental variations between countries.

\section{Conclusions}

Arising from the above discussion, it is evident that agricultural support institutions in all the political periods of the country had both a local and national character because of the policies which existed in each time period. For example, during the colonial period the Maize Control Board and Eastern Province Produce Board existed; after independence NAMBOARD, NCZ and ZCF were in existence and, FRA and FISP came up after the introduction of liberalization in 1991. The study has established that agricultural support institutions of pre-independence were few and located mainly in already developed areas; institutions which existed between 1964 and 1990 were mainly government owned and widespread; soon after the introduction of liberalization in 1991 many government agricultural support institutions collapsed and later after 1997 were replaced by privately owned, funded and controlled institutions. Institutions established between 1964 and 1990 were more spatially wide spread than those before independence and after 1990. This study has also established that institutions formed after 1991 were financially self sustaining unlike those of the pre-1991 days which were funded by government.

\section{Acknowledgements}

I thank all people who helped make this work possible. Some individuals worth mentioning by name are Dr. H.M. Sichingabula, Mr. Joseph Chalila, Mr. Evaristo Kapungwe and Mr. G.M. Kajoba. I also thank numerous officials of the Ministry of Agriculture and Cooperatives in Chibombo, Kapiri Mposhi and Mumbwa Districts. I equally want to extend thanks to the peasants of the three districts for supplying primary data for this study.

\section{References}

Bwalya, T. M., Nzala, A. B. K., \& Manda, P. H. (1994 \& 1997). Basic Education Atlas of Zambia. London: Macmillan Press Limited.

Chabala, C., \& Sakufiwa, E. (1993). Small-scale Maize Marketing, Handling and Storage in Zambia. Lusaka: IFAD Smallholder Services.

CSO. (2003). Agricultural and Population Census. Lusaka: Government Printers.

DACO-Chibombo. (2008). Minutes of Extension Work. Chibombo: Chibombo District Council.

DACO-Kapiri Mposhi. (2008). Minutes of Extension Work. Kapiri Mposhi: Kapiri Mposhi District Council.

DACO-Mumbwa. (2008). Minutes of Extension Work. Mumbwa: Mumbwa District Council.

Gerrard, C. D., Posehn, G. D., \& Ansong, G. (1994). Agricultural Pricing Policy in Eastern Africa: A macroeconomic simulation for Kenya, Malawi, Tanzania and Zambia. Washington D.C.: The World Bank.

GRZ. (1966). The First National Development Plan, 1966-1970. Lusaka: National Commission for Development Planning.

GRZ. (1971). Second National Development Plan, 1972-1976. Lusaka: National Commission for Development Planning.

GRZ. (1979). Third National Development Plan, 1979-1983. Lusaka: National Commission for Development Planning.

GRZ. (1992). A Framework for Agricultural Policies to the Year 2000 and Beyond. Lusaka: Government Printer.

Jacobsen, V., Scobie, G. M., \& Duncan, A. (1995). Statutory Intervention in Agricultural Marketing: A New Zealand Perspective. Washington D.C.: The World Bank.

Kadenge, P. G., Ndoro, H., \& Zwizwai, B. M. (1992). 'Zimbabwe's Structural Adjustment Programme: The first experience'. In A. M. Mwanza (Ed.), Structural Adjustment Programmes in SADC: Experiences and Lessons from Malawi, Tanzania, Zambia and Zimbabwe. Harare: Sapes Books.

Kaluwa, B., Silumba, E., Banda, E. N., \& Chilowa, W. (1992). The Structural Adjustment Programme in Malawi: A Case of Successful Adjustment? In A. M. Mwanza (Ed.), Structural Adjustment Programmes in SADC: Experiences and Lessons from Malawi, Tanzania, Zambia and Zimbabwe. Harare: Sapes Books.

Klepper, R. (1979). Zambian Agricultural Structure and Performance. In B. Turok (Ed.), Development in Zambia: A Reader. London: Zed Press.

Kokwe, G. M. (1997). Maize, Markets \& Livelihoods: State intervention and agrarian change in Luapula Province, Zambia, 1950-1995. Helsinki: Interkont Books. 
Meteorological Department. (2000). Summary rainfall data. Lusaka: Government Printers.

Mwanakasale, A. (1996). Government Withdraws from Credit Scheme. Zambian Farmer, 1(12), 6.

Mwanza, A. M. (1992). Structural Adjustment Programme in SADC: Experiences and Lessons from Malawi, Tanzania, Zambia and Zimbabwe. Harare: Sapes Trust.

Shao, I. F., Kiwara, A. D., \& Makusi, G. J. (1992). Structural Adjustment in a Socialist Country: The Case of Tanzania. In A. M. Mwanza (Ed.), Structural Adjustment Programmes in SADC: Experiences and Lessons from Malawi, Tanzania, Zambia and Zimbabwe. Harare: Sapes Books.

Shawa, J., \& Johnson, W. I. R. (1990). Historical Perspectives. In A. P. Wood, S. A. Kean, J. P. Milimo, \& D. M. Warren (Eds.), The Dynamics of Agricultural Policy and Reform in Zambia. Iowa: Iowa State University.

Silk, J. (1979). Statistical Concepts in Geography. London: George Allen \& Unwin.

Valdes, A., \& Schaeffer, B. (1995). Surveillance of Agricultural Price and Trade Policies: A handbook for Argentina. Washington D.C.: The World Bank.

World Bank. (1994). Adjustment in Africa: Reforms, Results, and the Road Ahead. Oxford: Oxford University Press.

\section{Copyrights}

Copyright for this article is retained by the author(s), with first publication rights granted to the journal.

This is an open-access article distributed under the terms and conditions of the Creative Commons Attribution license (http://creativecommons.org/licenses/by/3.0/). 